\title{
Hepatitis E virus infection in a patient with alcohol related chronic liver disease: a case report of acute-on-chronic liver failure
}

\author{
Anabella Fantilli ${ }^{{ }^{*+}+} \mathbb{D}$, Sarah Daniela López Villa ${ }^{2 \dagger}$, Alina Zerega ${ }^{3}$, Guadalupe Di Cola', Luis López², \\ Maribel Wassaf Martínez ${ }^{4}$, María Belén Pisano ${ }^{1}$ and Viviana Elizabeth Ré ${ }^{1}$
}

\begin{abstract}
Background: The hepatitis E virus (HEV) infection has been described as a causing factor for acute-on-chronic-liverfailure (ACLF) in patients with underlying chronic liver disease (CLD), such as chronic hepatitis or cirrhosis, which could end in the failure of one or more organs and high short-term mortality. There are scarce data about the association of HEV in patients with chronic liver disorders in South America.

Case presentation: A 56-year-old hypertensive male with a history of type 2 diabetes was diagnosed with alcoholrelated-liver cirrhosis in February 2019. A year later, the patient was admitted to hospital due to fatigue, jaundice and acholia. No evidence of hepatitis A virus, hepatitis B virus, hepatitis C virus, Epstein-Barr virus, herpes zoster virus and cytomegalovirus infections were found. Nevertheless, in February and March, 2020 the patient was positive for HEVIgM and HEV-lgG, and HEV genotype 3 RNA was detected in sera. Afterwards, he presented grade I hepatic encephalopathy and, therefore, was diagnosed with acute hepatitis E-on-chronic liver disease. The patient reported a recent travel to the Argentine coast, where he consumed seafood. Besides, he reveled to have consumed pork meat and had no history of blood transfusion.

Conclusion: This report describes a unique case of hepatitis E virus infection in a patient with alcohol-related cirrhosis. This is the first report of a patient with HEV-related ACLF in Argentina and it invokes the importance of HEV surveillance and treatment among patients with CLD, such as alcohol-related cirrhosis.
\end{abstract}

Keywords: HEV, Cirrhosis, Chronic liver disease, Acute-on-chronic hepatitis, Argentina

\section{Background}

The hepatitis E virus (HEV) (specie Orthohepevirus A, genus Ortohepevirus, family Hepeviridae) is a non-enveloped virus with a positive sense single stranded RNA genome. It is one of the leading causes of acute viral hepatitis of enteric transmission worldwide [1-3]. It has been

\footnotetext{
*Correspondence: anabellafantilli@gmail.com

${ }^{\dagger}$ Anabella Fantilli and Sarah Daniela López Villa have contributed equally to this work

${ }^{1}$ Instituto de Virología "Dr. J. M. Vanella"- InViV- CONICET, Facultad de Ciencias Médicas, Universidad Nacional de Córdoba, Enfermera Gordillo Gómez s/n, Ciudad Universitaria, CP 5016 Córdoba, Argentina

Full list of author information is available at the end of the article
}

classified into 8 genotypes (HEV-1 to HEV-8); genotypes 1 to 4 and 7 have been shown to infect humans [3, 4].

Epidemiological differences between genotypes have been reported, such as worldwide distribution, ways of transmission and clinical manifestations. It is well-known that, from the clinical perspective, HEV infections result in a spectrum of reported manifestations including acute infections, mostly asymptomatic, chronic hepatitis in individuals with immunosuppression and/or chronic liver disease (CLD), mainly associated with genotype HEV-3 and HEV-4, extrahepatic manifestations, fulminant hepatitis in pregnant women, when the infecting original author(s) and the source, provide a link to the Creative Commons licence, and indicate if changes were made. The images or other third party material in this article are included in the article's Creative Commons licence, unless indicated otherwise in a credit line to the material. If material is not included in the article's Creative Commons licence and your intended use is not permitted by statutory regulation or exceeds the permitted use, you will need to obtain permission directly from the copyright holder. To view a copy of this licence, visit http://creativecommons.org/licenses/by/4.0/. The Creative Commons Public Domain Dedication waiver (http://creativeco mmons.org/publicdomain/zero/1.0/) applies to the data made available in this article, unless otherwise stated in a credit line to the data. 
genotype is 1 , and in those individuals with other underlying liver diseases, such as CLD [5-10].

In South America, countries are mainly non-endemic for HEV, showing moderate HEV circulation. Sporadic acute HEV cases and a few cases of chronic hepatitis $E$ or HEV infection with extra hepatic complications have been informed. Only HEV-1 and HEV-3 have been detected, and HEV-3 is the most frequent genotype found in this region [11].

CLD is a pathology characterized by gradual and constant injury to the liver tissue caused by a wide variety of etiologies [12]. Various factors can shorten or accelerate this process of development. Thus, when acute viral hepatitis occurs in patients with CLD, they may develop an acute-on-chronic liver failure (ACLF) [12]. There is no consensus established about the conceptualization and characterization of this syndrome. The Asian Pacific Association for the Study of Liver (APASL), the European association for the study of liver (EASL) and the American association for the study of liver diseases (AASLD), define ACLF differently $[13,14]$.

Although there is no universally agreed definition of this entity, both, the West and the East, state that the acute deterioration of liver function in a patient with compensated chronic liver disease, mainly stable liver cirrhosis, is the characteristic feature of ACLF, and they consider $\mathrm{HEV}$ as a well-defined precipitating event that may cause ACLF [15]. There is only one previous case of HEV-related ACLF reported in Latin America, specifically in Peru [16].

The present study describes a case of acute hepatic deterioration caused by HEV infection in a patient with pre-existing CLD, specifically alcohol-related cirrhosis. This is the first report of a patient with HEV-related ACLF in Argentina.

\section{Case presentation}

A 56-year-old hypertensive male with a history of type 2 diabetes, diagnosed with alcohol-related-liver cirrhosis in February 2019, who presented variceal upper gastrointestinal bleeding at the beginning of the disease, was admitted to hospital in February 2020. He presented a 1-week history of general malaise that began with fatigue and then jaundice and acholia, without fever or abdominal pain. His treatment before hospitalization was propranolol $80 \mathrm{mg} /$ day, metformin $850 \mathrm{mg} /$ day and sitagliptin $50 \mathrm{mg} /$ day. He denied any alcohol, cigarettes or illicit drug consumption recently and reported a recent travel to the Argentine coast, where he consumed seafood. Besides, he reveled to have consumed pork meat and no history of blood transfusion.

Physical examination demonstrated he was normotensive, afebrile, with mucocutaneous jaundice.
Laboratory investigations showed elevated aspartate aminotransferase (AST) of $1347 \mathrm{IU} / \mathrm{mL}$; alanine aminotransferase (ALT) of $1387 \mathrm{IU} / \mathrm{mL}$, total bilirubin of $9 \mathrm{mg} / \mathrm{dL}$, alkaline phosphatase of $181 \mathrm{IU} / \mathrm{mL}$, international normalized ratio (INR) of 1.17 , plasma prothrombin activity (PPT) of 68\%, platelets of $159 \mathrm{~mL} /$ $\mathrm{mm} 3$, and total protein of $7.21 \mathrm{~g} / \mathrm{dL}$ (Table 1). Antinuclear antibody (ANA), antismooth muscle antibody (ASMA) and antimitochondrial antibodies (AMA) were negative. A complete blood count, creatinine and ionogram were in normal parameters. Abdominal magnetic resonance with contrast and cholangioresonance revealed liver that suggested CLD.

Serological tests for hepatitis A, B, and C viruses, Epstein-Barr virus, herpes zoster virus, and cytomegalovirus were negative. IgG and IgM anti-HEV antibodies were tested by third generation ELISA assays, using commercial kits (Diapro, Italy), following the manufacturer's instructions, revealing that this patient was HEV-IgM and HEV-IgG double positive in February and March, 2020. RT-real time PCR for molecular HEV screening was also carried out. Briefly, to obtain cDNA, retrotranscription was performed using random hexamer primers and the enzyme Reverse Transcriptase (ImPromII -Reverse Transcriptase- Promega), followed by genomic detection of HEV by real time PCR (iTaq Universal Probes Supermix- BIO-RAD) [17]. Both samples, obtained in February and March 2020, resulted positive. A nested-PCR, amplifying a $348 \mathrm{bp}$ fragment of the ORF-2 region for HEV 1-4 genotypes, using the enzyme GoTaq (Promega), previously described [18], was carried out, obtaining a positive result. The resulting amplicon was purified using a QIAquick Gel Extraction Kit (QIAGEN, Valencia, CA, USA) and subjected to direct nucleotide sequencing in both directions (Macrogen, Inc. Seoul, Korea): the presence of HEV genotype 3 was determined (Fig. 1).

Following admission, during the first days of March 2020, the patient's liver enzyme levels showed a downward trend with AST values of $151 \mathrm{IU} / \mathrm{mL}$, ALT of $150 \mathrm{IU} / \mathrm{mL}$ with rising hyperbilirubinemia and total bilirubin of $25.83 \mathrm{mg} / \mathrm{dL}$. At this stage, he evolved with signs of grade I hepatic encephalopathy (bradypsychia). Thus, the patient was diagnosed with acute hepatitis E-onchronic liver disease and was referred to a transplant center for treatment evaluation with a MELD score of 23 points (INR of 1.29 , creatinine of $1.14 \mathrm{mg} / \mathrm{dL}$, total bilirubin of $25.83 \mathrm{mg} / \mathrm{dL}$, Na of $131 \mathrm{mg} / \mathrm{dL}$ ) and MELD-Na score of 27 points. The patient was transplanted on May 19, 2020. The presence of IgM anti-HEV was negative and IgG anti-HEV was positive for successive serum samples in May, June and October, although HEV RNA could not be amplified during these months (Fig. 1), therefore, chronic infection by this agent was ruled out. 
Table 1 Clinicopathological parameters of the patient throughout different stages of hospitalization

\begin{tabular}{|c|c|c|c|c|c|c|c|}
\hline Laboratory parameters & $\begin{array}{l}\text { Hospital } \\
\text { admission } \\
02 / 2020\end{array}$ & $06 / 03 / 20$ & $\begin{array}{l}\text { Before 1st } \\
\text { transplant } \\
18 / 05 / 20\end{array}$ & $\begin{array}{l}\text { After 1st } \\
\text { transplant } \\
26 / 05 / 20\end{array}$ & $\begin{array}{l}\text { Cholestasis } \\
\text { event } \\
23 / 07 / 2020\end{array}$ & $\begin{array}{l}\text { Liver } \\
\text { resection 28/09/2020 }\end{array}$ & $\begin{array}{l}\text { Before 2nd } \\
\text { transplant } \\
23 / 03 / 21\end{array}$ \\
\hline ALP (UI/mL) & 181 & 141 & 64 & 232 & 451 & 630 & 242 \\
\hline AST $(U \mathrm{II} / \mathrm{mL})^{*}$ & 1347 & 151 & 50 & 565 & 45 & 42 & 17 \\
\hline $\operatorname{ALT}(\mathrm{UI} / \mathrm{mL}) *$ & 1387 & 150 & 40 & 1565 & 73 & 53 & 106 \\
\hline INR* & 1.17 & 1.29 & 1.9 & 1.09 & 1.03 & 1.1 & 1.3 \\
\hline PPA (\%) & 68 & 60 & 40 & 92 & 98 & 87 & 63 \\
\hline Creatinine $(\mathrm{mg} / \mathrm{dL}){ }^{*}$ & 0.84 & 1.14 & 1.6 & 0.9 & 0.7 & 0.8 & 1.7 \\
\hline Blood urea (mg/dL) & 27 & 55 & 45 & 38 & 48 & N/A & N/A \\
\hline Total bilirubin $(\mathrm{mg} / \mathrm{dL}) *$ & 9.18 & 25.83 & 11 & 4.6 & 8 & 10 & 4.3 \\
\hline Na levels $(\mathrm{mmol} / \mathrm{L}) *$ & 135.8 & 131 & 135 & 140 & 137 & 134 & 132 \\
\hline K levels (mmol/L) & 4.1 & 3.67 & 3.9 & 4.1 & 3.8 & 3.4 & 4.7 \\
\hline Cl levels (mmol/L) & 100.2 & 89.8 & 105 & 102 & 102 & 97 & 100 \\
\hline $\begin{array}{l}\text { Red cell count (mill/ } \\
\text { mm3) }\end{array}$ & 4.39 & 4.51 & 3.1 & 3.16 & 4.32 & 3.19 & 2.68 \\
\hline Hemoglobin (g/dL) & 14.4 & 15 & 10.5 & 10.5 & 14.4 & 9.9 & 8.6 \\
\hline Platelets (n\%mm3) & 159,000 & 165,000 & 113,000 & 209,000 & 234,000 & 196,000 & 128,000 \\
\hline $\begin{array}{l}\text { White cell blood count } \\
(\mathrm{n} \% \mathrm{~mm} 3)\end{array}$ & 6590 & 8820 & 9350 & 8680 & 3620 & 3510 & 12,900 \\
\hline Total proteins (g/dL) & 7.21 & 6.8 & N/A & 5.8 & N/A & N/A & N/A \\
\hline Encephalopathy & NO & YES & YES & NO & NO & NO & YES \\
\hline
\end{tabular}

N/A, not available; ALP, Alkaline phosphatase; AST, Aspartate aminotransferase; ALT, Alanine transaminase; INR, International normalized ratio; PPA, Plasma prothrombin activity

*Parameters used for the calculation of the MELD score

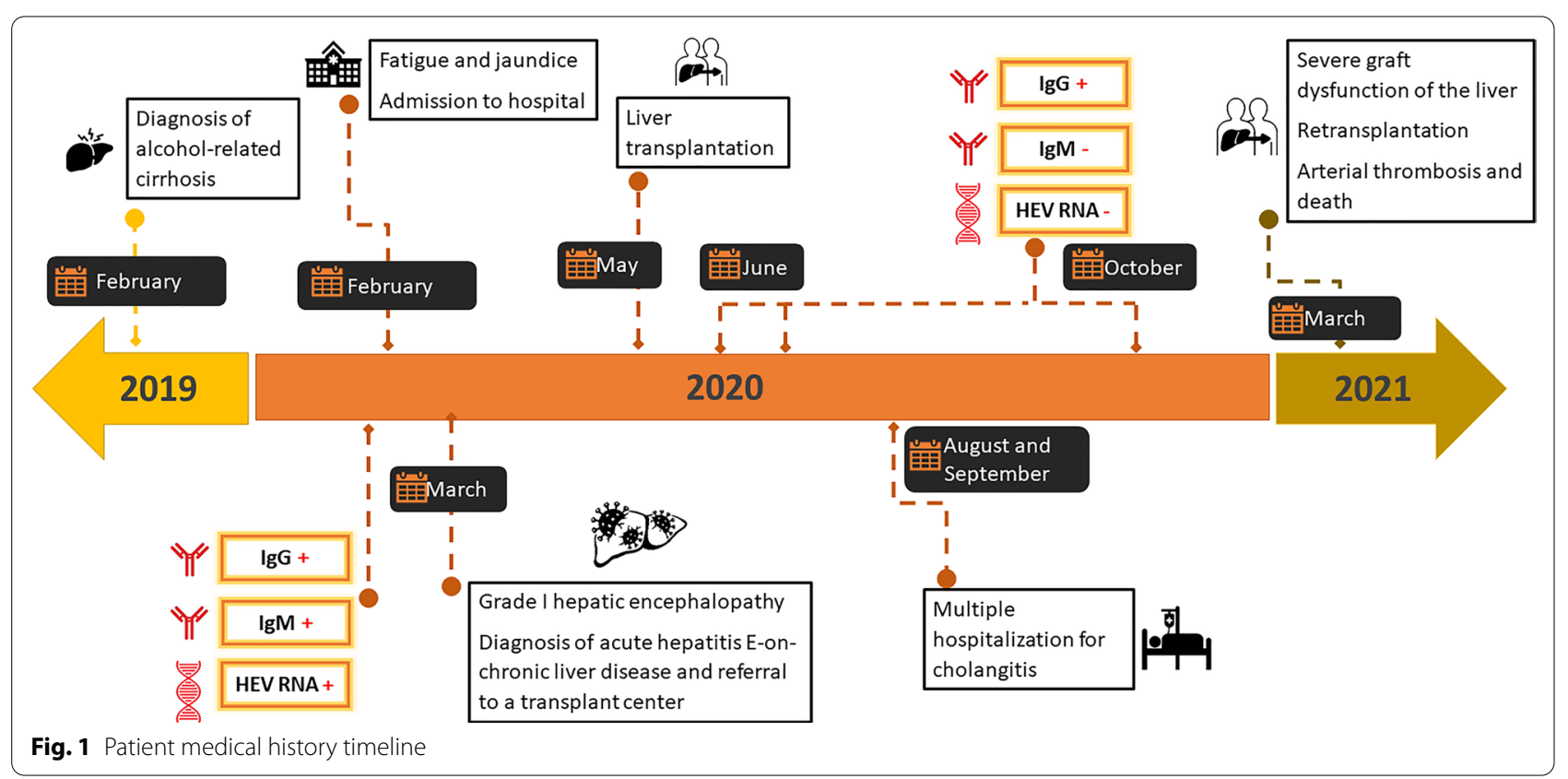

Throughout August and September, 2020, the patient had multiple hospitalizations for cholangitis. The following months he manifested a severe graft dysfunction of the liver; therefore, the patient underwent a liver retransplantation in March, 2021. Over the next days, he 
suffered an arterial thrombotic event and passed away on March 25, 2021.

Table 1 shows the clinicopathological parameters of this patient throughout different stages of hospitalization (during hospital admission, before and after the first and second transplant).

\section{Discussion and conclusions}

Herein, we present an acute-on-chronic liver failure case. Reports of clinically significant HEV cases are low or infrequent in South America, due to a high rate of asymptomatic or underdiagnosed cases in this region. To the best of our knowledge, this is the first published case of acute hepatitis $\mathrm{E}$ in a patient with chronic liver disease in Argentina.

In general, and as it can be specifically observed in this case, the causative relation between HEV infection and the development of ACLF is difficult to establish. On the one hand, it has been widely studied that there is a predisposition to acquire HEV among patients with underlying liver diseases, such as cirrhosis [19-22]. Some reports have documented that cirrhosis-associated immune dysfunction can lead to alterations in innate and acquired immunity, both at an intrahepatic and systemic level. This could, in theory, explain why patients with cirrhosis may be prone to contract HEV infection [23, 24]. On the other hand, there are also multiple studies conducted worldwide [12, 20, 25-34] that analyzed how HEV infection contributes to the progression of CLD, showing that HEV infection negatively impacts the survival and prognosis of this group of patients, and has been indicated as a promoting factor for the progression of cirrhosis and hepatocellular carcinoma. Therefore, it could be considered an important trigger of liver decompensation, high morbidity and lethality in patients with underlying liver diseases [12, 20, 25-34]. Accordingly, an increasing number of reports from Asia, an HEV-endemic area, shows strong evidence that suggests that HEV is a major cause of ACLF in patients previously diagnosed with CLD [28-30, 35-41]. In contrast, in Europe, Africa and North America there are still limited studies [12]. In this regard, in South America, two recent publications in Brazil and Argentina have documented a higher HEV seroprevalence in patients with CLD [19, 42], and there is only one previous case of HEV-related ACLF described in a patient from Peru who developed autoimmune hepatitis and severe hepatic decompensation associated to HEV infection [16]. Nevertheless, despite these associations and evidence of decompensation in patients with preexisting liver diseases, whether HEV causes fulminant hepatitis among those with chronic hepatic disorders from our region remains still unknown.
Another remarkable factor to be taken into account is that the etiology of cirrhosis in the present case was alcohol. Previous studies have proposed excessive alcohol consumption to be considered an important risk factor for HEV infection, as it contributes to the clinical expression of the infection and the severity of hepatitis, and it can induce subclinical liver disease (steatosis and/or fibrosis), which increases the susceptibility of the organ to develop viral symptomatic infections [43-45]. A previous study from France found that acute hepatitis $E$ in persons who had not travelled to HEV-endemic regions may cause fulminant hepatitis, especially in those with active alcohol use [46].

Particularly, in the last years, there have been two studies that describe a significant association between alcoholic-related cirrhosis and HEV infection [21, 42]. In one of them, conducted in the same region from Argentina by our research group, it was reported a high HEV seroprevalence in patients with alcoholic-related cirrhosis, an indication that this group may be prone to contract HEV infection [42]. Moreover, Lin et al. [33] reported a recent case of HEV reinfection in a patient with liver cirrhosis who had rapid hepatocellular carcinoma development, which highlights the important role of HEV in the progression in liver cirrhosis cases, and how a functional decompensated liver predisposes patients to HEV infection.

In our study, the patient reveled that he had traveled to the coast and consumed seafood previous to the onset of symptoms, as well as pork meat consumption. Both types of food have been reported to be means of transmission for HEV [47], although we cannot assure that some of these have been the transmission route, which could be considered a limitation of our study. An additional source of infection for this case could have been contact with contaminated matrices of water, since Argentina has reported the presence of viruses in recreational waters [11]. Although it has been shown that HEV can be transmitted by blood transfusions [11], this route was ruled out since the patient did not receive transfusions during the hospitalization period.

The genotype found in the present case was HEV3 , which is especially associated to chronic infection $[48,49]$. This result coincides with previous information about circulating genotypes in this region of South America, where only HEV-1 and HEV-3 have been detected. Particularly, HEV-3 is the most frequent genotype detected in Argentina and it was previously isolated from humans, pigs and environmental samples [11]. Although persistent RNA replication was not found for more than 3 months in our patient, it is well documented that cases of chronic HEV have mostly been observed in immunocompromised people, such 
as transplanted patients, and in those with underlying chronic diseases, who are at major risk of developing chronic HEV infection when the infecting genotype is HEV-3 [50, 51].

In conclusion, herein we report the first patient with hepatitis E-related ACLF in Argentina. In our region, HEV is not considered a causative agent of hepatitis, and in less levels among patients with CLD; accordingly, the evidence in this report contributes to making this agent visible as a cause of liver disease. Additionally, although the natural history of hepatitis $E$ in patients with CLD is not well understood yet and could not be deeply studied in this case, an acute HEV infection, with the possibility of the development of chronicity, might be a reason of morbidity and finally death in groups of patients with these pathologies. This unique case invokes the importance of HEV surveillance and treatment among patients with CLD. Thus, prompt recognition and diagnosis of HEV should be improved to develop more effective and earlier interventions, by increasing awareness and knowledge of basic and clinical aspects of the disease.

\section{Abbreviations}

HEV: Hepatitis E virus; ACLF: Acute-on-chronic liver failure; CLD: Chronic liver disease; APASL: Asian Pacific Association for the study of liver; EASL: European association for the study of liver; AASLD: American association for the study of liver diseases; AST: Aspartate aminotransferase; ALT: Alanine aminotransferase; ALP: Alkaline phosphatase; INR: International normalized ratio; PPA: Plasma prothrombin activity; ANA: Antinuclear antibody; ASMA: Antismooth muscle antibody; AMA: Antimitochondrial antibodies.

\section{Acknowledgements}

Not applicable.

\section{Authors' contributions}

AZ, SDLV, MBP, VER made substantial contributions to the conception and conceptualization; AF, MBP, GDC, VER, MMW analyzed and interpreted the patient data; SDLV, AZ, LL performed the acquisition, analysis and interpretation of the patient medical data; AF was in charge of data curation; AF, MBP, and VER wrote the original draft; all authors read and approved the final manuscript.

\section{Funding}

This work was supported by the Agencia Nacional de Promoción de Ciencia y Técnica de Argentina, ANPCyT, Foncyt, grant numbers PICT-2016-0143 and 2019-2222 to VR; and Fundación Bunge y Born grant number 2-2019 to MBP. None of the funding sources stated had any influence on the study design, interpretation of data, or writing of the manuscript.

\section{Availability of data and materials}

Not applicable.

\section{Declarations}

\section{Ethics approval and consent to participate}

This study was carried out in accordance with the requirements of the Ministry of Health of Córdoba Province and complied with the ethical standards of the Helsinki Declaration of the World Medical Association.

\section{Consent for publication}

Written informed consent for publication was obtained from the patient's next to kin.

\section{Competing interests}

The authors declare that they have no competing interests.

\section{Author details}

1'Instituto de Virología "Dr. J. M. Vanella"- InViV- CONICET, Facultad de Ciencias Médicas, Universidad Nacional de Córdoba, Enfermera Gordillo Gómez s/n, Ciudad Universitaria, CP 5016 Córdoba, Argentina. ${ }^{2}$ Instituto Modelo de Cardiología, Córdoba, Argentina. ${ }^{3}$ Sanatorio Allende, Córdoba, Argentina. ${ }^{4}$ LACE Laboratorios, Córdoba, Argentina.

Received: 30 July 2021 Accepted: 26 November 2021

Published online: 09 December 2021

\section{References}

1. Smith DB, Simmonds P, Izopet J, Oliveira-Filho EF, Ulrich RG, Johne R, et al. Proposed reference sequences for hepatitis E virus subtypes. J Gen Virol. 2016;97:537-42.

2. World Health Organization (WHO). Fact Sheet HEV. 2017.

3. Sridhar S, Teng J, Chiu T, Lau S, Woo P. Hepatitis E virus genotypes and evolution: emergence of camel hepatitis E variants. Int J Mol Sci. 2017;18:1-19.

4. Smith D, Simmonds P. Classification and genomic diversity of enterically transmitted hepatitis viruses. Cold Spring Harb Perspect Med. 2018;8(9): https://doi.org/10.1101/cshperspect.a031880.

5. Doceul V, Bagdassarian E, Demange A, Pavio N. Zoonotic hepatitis E virus: classification, animal reservoirs and transmission routes. Viruses. 2016;8(10):1-24.

6. Gupta E, Agarwala P. Hepatitis e virus infection: an old virus with a new story! Indian J Med Microbiol. 2018;36(3):317-23. https://doi.org/10.4103/ ijmm.IJMM_18_149.

7. Lhomme S, Marion O, Abravanel F, Izopet J, Kamar N. Clinical manifestations, pathogenesis and treatment of hepatitis E virus infections. J Clin Med. 2020;9(2):331. https://doi.org/10.3390/jcm9020331.

8. Aslan AT, Balaban HY. Hepatitis E virus: epidemiology, diagnosis, clinical manifestations, and treatment. World J Gastroenterol. 2020;26(37):5543-60

9. Navaneethan U, Al Mohajer M, Shata MT. Hepatitis E and pregnancy: understanding the pathogenesis. Liver Int. 2008;28(9):1190-9.

10. Fousekis FS, Mitselos IV, Christodoulou DK. Extrahepatic manifestations of hepatitis E virus: an overview. Clin Mol Hepatol. 2020;26(1):16-23.

11. Pisano MB, Martinez-Wassaf MG, Mirazo S, Fantilli A, Arbiza J, Debes JD, et al. Hepatitis E virus in South America: the current scenario. Liver Int. 2018;38(9):1536-46.

12. Frias M, López-López P, Rivero A, Rivero-Juarez A. Role of hepatitis e virus infection in acute-on-chronic liver failure. Biomed Res Int. 2018;2018:9098535. https://doi.org/10.1155/2018/9098535

13. Sarin SK, Choudhury A, Sharma MK, Maiwall R, Al Mahtab M, Rahman S, et al. Acute-on-chronic liver failure: consensus recommendations of the Asian Pacific association for the study of the liver (APASL): an update. Vol. 13, Hepatology International. 2019. 353-390 p.

14. Olson JC, Kamath PS. Acute-on-chronic liver failure: What are the implications? Curr Gastroenterol Rep. 2012;14(1):63-6.

15. Kumar A, Saraswat VA. Hepatitis E and acute on chronic liver failure. J Clin Exp Hepatol. 2013;3:225-30.

16. Valenzuela V, Pinto J, Padilla M, Piscoya A, De los Rios R, Surco Y, et al. Severa descompensación por virus de hepatitis E en una paciente con hepatitis autoinmune: reporte de un caso. Rev gastroenterol Perú. 2012:32(2):187-91.

17. Jothikumar N, Cromeans TL, Robertson BH, Meng XJ, Hill VR. A broadly reactive one-step real-time RT-PCR assay for rapid and sensitive detection of hepatitis E virus. J Virol Methods. 2006;131:65-71. 
18. Huang FF, Haqshenas G, Guenette DK, Halbur PG, Schommer SK, Pierson FW, et al. Detection by reverse transcription-PCR and genetic characterization of field isolates of swine hepatitis $E$ virus from pigs in different geographic regions of the United States. J Clin Microbiol. 2002;40:1326-32.

19. Bricks G, Senise JF, Pott-Jr H, Grandi G, Carnaúba-Jr D, de Moraes HAB, et al. Previous hepatitis E virus infection, cirrhosis and insulin resistance in patients with chronic hepatitis C. Brazilian J Infect Dis. 2019;23(1):45-52. https://doi.org/10.1016/j.bjid.2019.02.002.

20. Riveiro-Barciela M, Buti M, Homs M, Campos-Varela I, Cantarell C, Crespo $M$, et al. Cirrhosis, liver transplantation and HIV infection are risk factors associated with hepatitis E virus infection. PLOS ONE. 2014;9(7):5-10.

21. Yang $H$, Wu J, Yuan $Y$, Huang W, Jia B. Retrospectively Seroprevalence Study on Anti-HEV- IgG antibody in patients with chronic hepatitis or liver cirrhosis in a Chinese teaching hospital. J Med Virol. 2019;91(3):437-43. https://doi.org/10.1002/jmv.25335.

22. Akyüz F, Çavuş B, Pınarbaşı B, Bozacı M, Baran B, Akyuz U, et al. Cryptogenic liver cirrhosis and hepatitis E virus (HEV): are they related? Ann Hepatol. 2019;18:585-9.

23. Albillos A, Lario M, Álvarez-Mon M. Cirrhosis-associated immune dysfunction: distinctive features and clinical relevance. J Hepatol. 2014;61:1385-96

24. Sipeki N, Antal-Szalmas P, Lakatos P, Papp M. Immune dysfunction in cirrhosis. World J Gastroenterol. 2014;20:2564-77.

25. Dalton H, Hazeldine S, Banks M, ljaz S, Bendall R. Locally acquired hepatitis E in chronic liver disease. Lancet. 2007;369(9569):1260.

26. Atiq M, Shire NJ, Barrett A, Rouster SD, Sherman KE, Shata MT. Hepatitis E virus antibodies in patients with chronic liver disease. Emerg Infect Dis. 2009;15(3):479-81.

27. van der Eijk AA, Pas SD, de Man RA. Hepatitis E virus: a potential threat for patients with liver disease and liver transplantation. Best Pract Res Clin Gastroenterol. 2017;31(2):143-50. https://doi.org/10.1016/j.bpg.2017.03. 006.

28. Kumar Acharya S, Kumar Sharma P, Singh R, Kumar Mohanty S, Madan K, Kumar Jha J, et al. Hepatitis E virus (HEV) infection in patients with cirrhosis is associated with rapid decompensation and death. J Hepatol. 2007;46(3):387-94.

29. Krishna YR, Saraswat VA, Das K, Himanshu G, Yachha SK, Aggarwal R, et al. Clinical features and predictors of outcome in acute hepatitis $A$ and hepatitis E virus hepatitis on cirrhosis. Liver Int. 2009;29(3):392-8.

30. Ramachandran J, Eapen C, Kang G, Abraham P, Hubert DDJ, Kurian $G$, et al. Hepatitis E superinfection produces severe decompensation in patients with chronic liver disease. J Gastroenterol Hepatol. 2004;19(2):134-8

31. Hoan NX, Van TH, Hecht N, Sy BT, Marcinek P, Meyer CG, et al. Hepatitis $E$ virus superinfection and clinical progression in hepatitis $B$ patients. EBioMedicine. 2015;2(12):2080-6. https://doi.org/10.1016/j.ebiom.2015. 11.020 .

32. Marion-Audibert AM, Tesse S, Graillot E, Phelip G, Radenne S, Duperret S, et al. Lethal acute HEV superinfection on hepatitis B cirrhosis. Gastroenterol Clin Biol. 2010;34:334-6.

33. Lin XN, Hou J, Lin QX, Li SM, Chen R, Xie KP. Hepatitis E virus re-infection accelerates hepatocellular carcinoma development and relapse in a patient with liver cirrhosis: a case report and review of literature. World Hepatol. 2020;12(12):1358-66.

34. Tseng TC, Liu CJ, Chang CT, Su TH, Yang WT, Tsai CH, et al. HEV superinfection accelerates disease progression in patients with chronic HBV infection and increases mortality in those with cirrhosis. J Hepatol. 2020;72(6):1105-11. https://doi.org/10.1016/j.jhep.2020.01.012.

35. Garg H, Kumar A, Garg V, Sharma P, Sharma BC, Sarin SK. Clinical profile and predictors of mortality in patients of acute-on-chronic liver failure. Dig Liver Dis. 2012;44(2):166-71.

36. Hamid SS, Atiq M, Shehzad F, Yasmeen A, Nissa T, Salam A, et al. Hepatitis E virus superinfection in patients with chronic liver disease. Hepatology. 2002;36(2):474-8.

37. Ke WM, Li XJ, Yu LN, Lai J, Li XH, Gao ZL, et al. Etiological investigation of fatal liver failure during the course of chronic hepatitis $B$ in southeast China. J Gastroenterol. 2006;41(4):347-51.

38. Kumar A, Aggarwal R, Naik S, Saraswat V, Ghoshal U, Naik S. Hepatitis E virus is responsible for decompensation of chronic liver disease in an endemic region. Indian J Gastroenterol. 2004;23(2):59-62.
39. Kumar A, Das K, Sharma P, Mehta V, Sharma BC, Sarin SK. Hemodynamic studies in acute-on-chronic liver failure. Dig Dis Sci. 2009;54(4):869-78.

40. Zhang S, Chen C, Peng J, Li X, Zhang D, Yan J, et al. Investigation of underlying comorbidities as risk factors for symptomatic human hepatitis E virus infection. Aliment Pharmacol Ther. 2017;45(5):701-13.

41. Zhang X, Ke W, Xie J, Zhao Z, Xie D, Gao Z. Comparison of effects of hepatitis e or A viral superinfection in patients with chronic hepatitis B. Hepatol Int. 2010;4(3):615-20.

42. Fantilli AC, Trinks J, Marciano S, Zárate F, Balderramo DC, Wassaf MGM, et al. Unexpected high seroprevalence of hepatitis e virus in patients with alcohol-related cirrhosis. PLOS ONE. 2019;14(10):1-9.

43. Dalton $H$, Bendall $R$, Rashid M, Ellis V, Ali R, Ramnarace $R$, et al. Host risk factors and autochthonous hepatitis E infection. Eur J Gastroenterol Hepatol. 2011;23(12):1200-5.

44. Said B, Ijaz S, Kafatos G, Booth L, Thomas H, Walsh A, et al. Hepatitis E outbreak on cruise ship. Emerg Infect Dis. 2009;15:1738-44.

45. Szabo G, Saha B. Alcohol's effect on host defense. Alcohol Res Curr Rev. 2015;37(2):159-70.

46. Péron JM, Bureau C, Poirson H, Mansuy JM, Alric L, Selves J, et al. Fulminant liver failure from acute autochthonous hepatitis $E$ in France: description of seven patients with acute hepatitis $E$ and encephalopathy. J Viral Hepat. 2007;14(5):298-303.

47. Di Cola G, Fantilli AC, Pisano MB, Ré VE. Foodborne transmission of hepatitis $A$ and hepatitis E viruses: a literature review. Int J Food Microbiol. 2020;338: https://doi.org/10.1016/j.ijfoodmicro.2020.108986.

48. Kamar N, Selves J, Mansuy JM, Ouezzani L, Peron JM, Guitard J, et al. Hepatitis $\mathrm{E}$ virus and chronic hepatitis in organ-transplant recipients. $N$ Engl J Med. 2008;358:811-7.

49. Narayanan S, Abutaleb A, Sherman KE, Kottilil S. Clinical features and determinants of chronicity in hepatitis E virus infection. J Viral Hepat. 2019;26(4):414-21.

50. Abravanel F, Lhomme S, Chapuy-Regaud S, Mansuy JM, Muscari F, Sallusto F. Hepatitis E virus reinfections in solid-organ-transplant recipients can evolve into chronic infections. J Infect Dis. 2014;209:1900-6.

51. Haagsma E, Niesters H, van den Berg A, Riezebos-Brilman A, Porte R, Vennema $\mathrm{H}$, et al. Prevalence of hepatitis $\mathrm{E}$ virus infection in liver transplant recipients. Liver Transplant. 2009;15:1225-8.

\section{Publisher's Note}

Springer Nature remains neutral with regard to jurisdictional claims in published maps and institutional affiliations.

Ready to submit your research? Choose BMC and benefit from

- fast, convenient online submission

- thorough peer review by experienced researchers in your field

- rapid publication on acceptance

- support for research data, including large and complex data types

- gold Open Access which fosters wider collaboration and increased citations

- maximum visibility for your research: over $100 \mathrm{M}$ website views per year

At BMC, research is always in progress.

Learn more biomedcentral.com/submissions 